\title{
ANALISIS KEBERLANJUTAN USAHA BUDIDAYA BANDENG
}

\author{
SUSTAINABILITY ANALYSIS OF MILKFISH CULTIVATION
}

\author{
MAULI SOFI AGUSTIN DAN FUAD HASAN* \\ Program Studi Agribisnis Fakultas Pertanian Universitas Trunojoyo Madura \\ *Email: fuadhasan@trunojoyo.ac.id
}

\begin{abstract}
ABSTRAK
Bandeng adalah salah satu komoditas unggulan perikanan budidaya di Kabupaten Gresik. Pergeseran lahan budidaya menjadi kawasan industri yang terjadi di Gresik menjadi ancaman terhadap keberlanjutan usaha budidaya perikanan bandeng. Kecamatan Manyar merupakan salah satu kecamatan yang terdampak oleh alih fungsi lahan tersebut. Penelitian ini bertujuan untuk menganalisis keberlanjutan budidaya bandeng di pada dimensi ekologi, ekonomi dan sosial. Lokasi penelitian di Desa Banyuwangi Kecamatan Manyar Kabupaten Gresik pada bulan Januari 2021. Pengumpulan data primer dilakukan melalui wawancara, dan kuisioner terhadap 31 petani. Analisis data dilakukan dengan metode Multi Dimensional Scalling melalui pendekatan Rapfish. Hasil analisis menunjukkan kondisi keberlanjutan usaha budidaya bandeng pada dimensi ekologi adalah buruk $(22,98)$, dimensi ekonomi adalah kurang berkelanjutan $(40,90)$, dan dimensi sosial adalah kurang berkelanjutan $(43,45)$.
\end{abstract}

Kata kunci: bandeng, keberlanjutan, Rapfish,

\begin{abstract}
Milkfish is one of the leading aquaculture commodities in Gresik Regency. The shift of cultivated land into industrial areas in Gresik is a threat to the sustainability of milkfish aquaculture business. Manyar District is one of the district affected by the land conversion. The study aims to analyze the sustainability of milkfish cultivation on the ecological, economic and social dimensions. Research sites in Banyuwangi, Manyar District, Gresik Regency in January 2021. Primary data was collected used interview and questionnaires of 31 farmers. Data analysis used the Multi-Dimensional Scaling method through the rapfish approach. The results of the analysis show that the condition of the sustainability of milkfish cultivation on ecological dimension in bad sustainable $(22,98)$, the economic dimension in less sustainable $(40,90)$, and the social dimension is less sustainable $(43,45)$
\end{abstract}

Keywords: milkfish, sustainability, Rapfish,

\section{PENDAHULUAN}

Potensi Perikanan Indonesia telah dimanfaatkan dalam berbagai aktivitas ekonomi, salah satunya melalui perikanan budidaya. Pemanfaatan sumberdaya perikanan telah memberikan manfaat secara ekonomi kepada pelaku usaha maupun negara. Peningkatan nilai PDB perikanan dari tahun 2011 sebesar 154.545,2 Triliun Rupiah menjadi
227.278,9 Triliun Rupiah pada 2018 (BPS, 2018) menjadi bukti besarnya manfaat yang diperoleh melalui sumberdaya perikanan. Hal tersebut berbanding lurus dengan kebutuhan konsumsi ikan di Indonesia yaitu tahun $2015 \quad(40,90$ kg/kapita), tahun 2016 (43,88 kg/kapita), dan tahun 2017 (47,12 kg/kapita) yang cenderung mengalami peningkatan (BPS, 2018). Besarnya manfaat yang diperoleh 
melalui sumberdaya perikanan harus dibarengi dengan pengolahan sumberdaya untuk menjaga keberlanjutan dan mengurangi dampak negatif akibat pembangunan yang mempengaruhi sumberdaya perikanan dan lingkungan (Amna, 2014).

Gresik merupakan Kabupaten di Jawa Timur yang berpotensi dalam pengembangan perikanan budidaya. Salah satu komoditas utama yang dikembangkan oleh Pemerintah Kabupaten Gresik adalah bandeng. Hal tersebut didukung oleh luasan lahan tambak sebesar 30\% dari Jawa Timur berada di Kabupaten Gresik (BPS, 2019). Menurut Zakiyah (2014) terjadi pergeseran penggunaan kawasan tambak menjadi kawasan industri. Perubahan tersebut berpengaruh terhadap penurunan kualitas air pada lahan budidaya tambak. Konsentrasi timbal pada perairan Gresik mencapai 2,27 jauh lebih tinggi dibandingkan ketentuan pemerintah untuk kandungan timbal pada air sehat. Permasalahan lain yang muncul yaitu tingginya suhu air yang melebihi batas normal yaitu $35^{\circ} \mathrm{C}-37^{\circ} \mathrm{C}$ yang seharusnya mencapai $26^{\circ} \mathrm{C}-30^{\circ} \mathrm{C}$ sehingga dapat mempengaruhi keberlanjutan budidaya bandeng di Kabupaten Gresik.

Manyar merupakan salah satu Kecamatan di Gresik yang banyak membudidayakan komoditas bandeng. Masyarakat setempat telah menjadikan usaha budidaya bandeng sebagai sumber mata pencaharian utama yakni sekitar $40 \%$ total rumah tangga (20.908) yang menggantungkan hidup dari perikanan budidaya (BPS, 2019). Namun dalam perkembangannya, Kecamatan Manyar telah banyak berubah menjadi kawasan industri yang mengakibatkan tergesernya lahan budidaya perikanan termasuk komoditas bandeng. Padahal Pemerintah Kabupaten Gresik telah berkomitmen mengurangi alih fungsi lahan melalui perikanan berkelanjutan (Wijaya \& Rachmawati, 2017).

Berdasarkan hasil pra survei kepada petambak bandeng di Kecamatan Manyar sebanyak 5 orang, diketahui bahwa petambak merasakan adanya penurunan jumlah produksi bandeng pada luasan tambak yang sama dengan penurunan ratarata sebesar $40 \%$ selama 2 tahun terakhir. Faktor yang mempengaruhi penurunan produksi yaitu mahalnya harga input, perubahan iklim yang tidak menentu, penurunan kualitas lahan dan air, serta polusi udara. Dengan penurunan jumlah produksi maka berdampak terhadap penurunan pendapatan yang diterima petani. 
Permasalah alaih fungsi lahan, kualitas air, dan kenaikan biaya tersebut mengancam keberlanjutan budidaya bandeng. Pembangunan perikanan berkelanjutan memiliki tiga pilar utama yakni ekologi, ekonomi, dan sosial (Purwaningsih \& Santosa, 2015). Stremiekiene \& Ciegis (2007) dalam Faridz et al. (2018) menyatakan ketiga pilar harus dijaga pada tingkat yang wajar agar tidak terjadi trade off dalam upaya pembangunan. Menurut Asche et al. (2018), tiga pilar keberlanjutan saling memperkuat satu sama lain, tergantung pada sistem pengelolaan yang dilakukan.. Tujuan keberlanjutan adalah pembangunan dan pengentasan kemiskinan sehingga keberlanjutan sosial dan keberlanjutan ekonomi tergantung pada keberlanjutan ekologi (Rice, 2014).

Berdasarkan permasalahan di atas, penelitian ini bertujuan untuk menganalisis keberlanjutan budidaya bandeng di Kecamatan Manyar Kabupaten Gresik pada dimensi ekologi, ekonomi dan sosial.

\section{METODE PENELITIAN}

\section{Lokasi dan Waktu Penelitian}

Lokasi penelitian ditentukan secara sengaja (purposive) yaitu di Desa Banyuwangi Kecamatan Manyar Kabupaten Gresik dengan pertimbangan bahwa Kecamatan Manyar merupakan kecamatan yang mempunyai produksi perikanan terbesar yaitu $17 \%$ dari total produksi perikanan di Gresik (BPS, 2019) dan maraknya industri, konversi lahan, dan sarana perairan (Anggraini \& Sulistyarso, 2014) di Desa Banyuwangi. Penelitian dilakukan pada bulan Januari - Februari 2021

\section{Teknik Sampling dan Pengumpulan Data}

Sampel penelitian sejumlah 31 orang petani bandeng diambil dengan teknik simple random sampling. Pengumpulan data dari responden dilakukan menggunakan kuisioer untuk data yang dianalisis dan menggunakan wawancara untuk memperdalam pembahasan. Kuisioner yang disebar menggunakan skoring $0-3(0=$ buruk, $1=$ sedang, $2=$ baik, dan 3 = sangat baik).

Keberlanjutan budidaya bandeng diukur dengan tiga dimensi yang diadopsi dari Graha (2017) yaitu dimensi ekologi, ekonomi, dan sosial. Dimensi ekologi merupakan cerminan kegiatan pemanfaatan sumberdaya perikanan yang menekankan keseimbangan ekosistem yang mencakup kehidupan biologi dan alam. Atribut untuk dimensi ekologi antara lain: pencemaran perairan, ketersediaan air, tekanan pemanfaatan terhadap perairan, perubahan 
ukuran ikan, kondisi saluran air, dan perkembangan hama dan penyakit

Dimensi ekonomi merupakan cerminan kegiatan pemanfatan sumberdaya perikanan yang dapat memberikan keuntungan yang berkelanjutan. Atribut untuk dimensi ekonomi diadopsi dari Nirgasari (2015) yaitu keuntungan, pendapatan kotor, persaingan antar petambak, subsidi, permintaan ikan, harga ikan, biaya usahatani, dan jumlah produksi

Dimensi sosial merupakan cerminan orientasi sosial (masyarakat) yang dapat mendukung/tidak kesejahteraan melalui pembangunan perikanan secara jangka panjang dan berkelanjutan. Atribut untuk dimensi sosial diadopsi dari Graha (2017) dan Nirgasari (2015) yaitu pemahaman lingkungan, konflik, partisipasi keluarga, frekuensi pertemuan antar petambak tentang pengelolaan sumberdaya perikanan, ketergantungan pada sektor perikanan, keinginan meninggalkan lokasi, keamanan tambak, dukungan pihak lain, tawaran penjualan tanah, dan peran kelompok tani

\section{Metode Analisis Data}

Data dianalisis menggunakan Rapfish (Rapid Appraisal for Fisheries Analysis). Teknik ini berfungsi untuk mengevaluasi keberlanjutan perikanan secara multidisipliner yang dikembangkan oleh University of British Columbia Canada. Rapfish didasarkan pada teknik ordinasi menggunakan Multi-Dimensional Scalling (MDS). Uji statistik yang dilakukan meliputi: Leverage Analysis dan Multi Dimensional Scalling (MDS)

\section{Leverage Analysis bertujuan} mengetahui hubungan masing-masing atribut terhadap status keberlanjutan budidaya bandeng. Analisis ini dapat menunjukkan atribut mana yang dianggap paling berpengaruh baik/buruk terhadap status keberlanjutan. Penentuan atribut sensitif dilakukan berdasarkan urutan prioritas dengan melihat nilai Root Mean Square (RMS) ordinasi pada sumbu X. Semakin besar nilai RMS maka peranan atribut semakin besar dalam status keberlanjutan usaha budidaya bandeng.

Multi Dimensional Scalling (MDS) bertujuan mengetahui posisi keberlanjutan berdasarkan skala indeks keberlanjutan pada usaha budidaya bandeng di Kecamatan Manyar. Dengan menggunakan analisis MDS dapat diketahui nilai stress dan koefisien determinasi $\left(\mathrm{R}^{2}\right)$. Nilai stress yang diperbolehkan adalah dibawah 0,25. Skala indeks keberlanjutan berselang 0100 dengan kategori keberlanjutan yaitu: 0,00-25,00 (buruk), 25,00-50,00 (kurang ), 50,00-75,00 (cukup) dan 75,00-100 (baik). 
HASIL DAN PEMBAHASAN

Keberlanjutan Usaha Budidaya

\section{Bandeng di Kecamatan Manyar}

Perikanan berkelanjutan merupakan kegiatan mengusahakan sumberdaya ikan dengan memperhatikan faktor ekologi, ekonomi dan sosial untuk kebutuhan di masa mendatang. Hasil analisis multidimensi rapfish menggunakan dengan mengakomodasi semua dimensi menunjukkan nilai sebesar 35,87 (Gambar 1) yang berarti usaha budidaya bandeng di Kecamatan Manyar kurang berkelanjutan dengan nilai indeks berada pada skala 25,00-50,00. Menurut Erwina et al. (2015) kategori tersebut mencerminkan kondisi kurang menguntungkan bagi pengelolaan berkelanjutan.

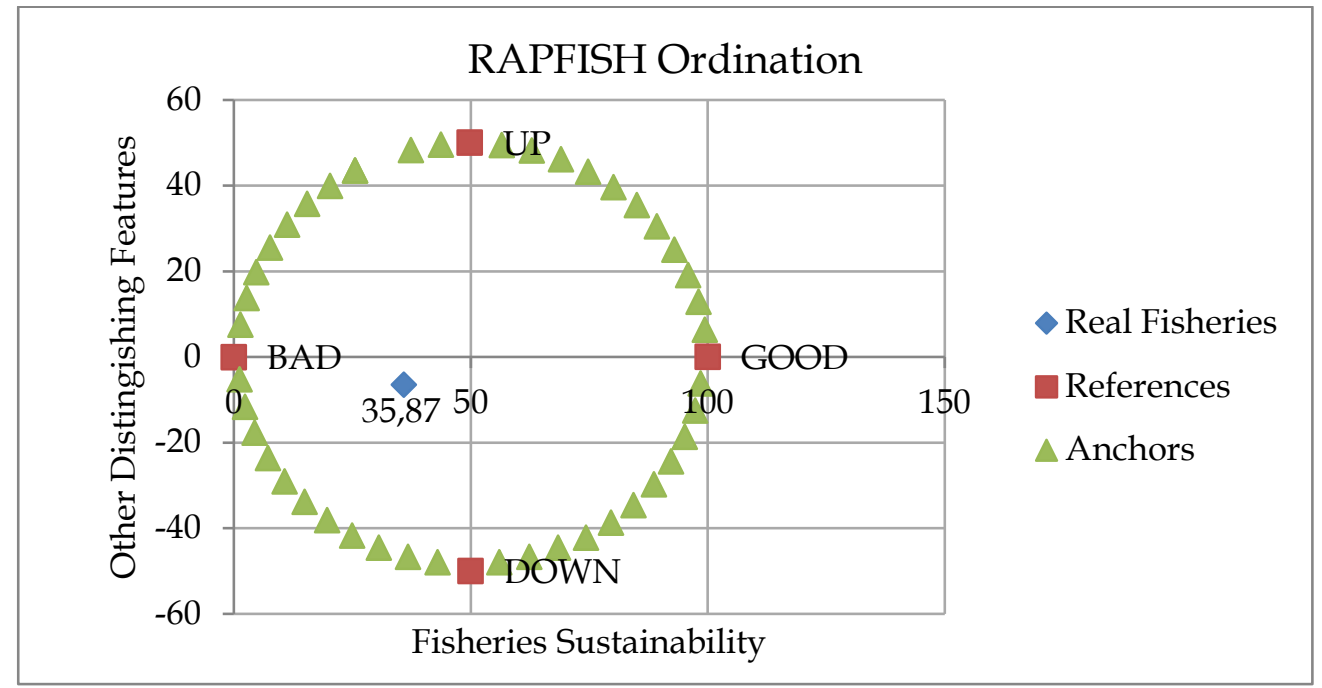

Gambar 1

Analisis Multidimensi Usaha Budidaya Bandeng

Berdasarkan hasil analisis setiap dimensi diketahui tidak terdapat satupun dimensi yang diukur pada kondisi baik. Dimensi ekonomi $(40,90)$ dan dimensi sosial $(43,45)$ berada pada kategori kurang berkelanjutan, sedangkan dimensi ekologi $(22,98)$ memiliki kategori keberlanjutan yang buruk (Gambar 2,4,\&6). Berikut penjelasan masing-maising dimensi
Status Keberlanjutan Dimensi Ekologi

Hasil analisis status keberlanjutan dimensi ekologi di Kecamatan Manyar menunjukkan nilai sebesar 22,98 (gambar 3). Nilai tersebut berada pada kategori buruk/tidak berkelanjutan dengan nilai indeks berada pada skala 00,00-25,00. 


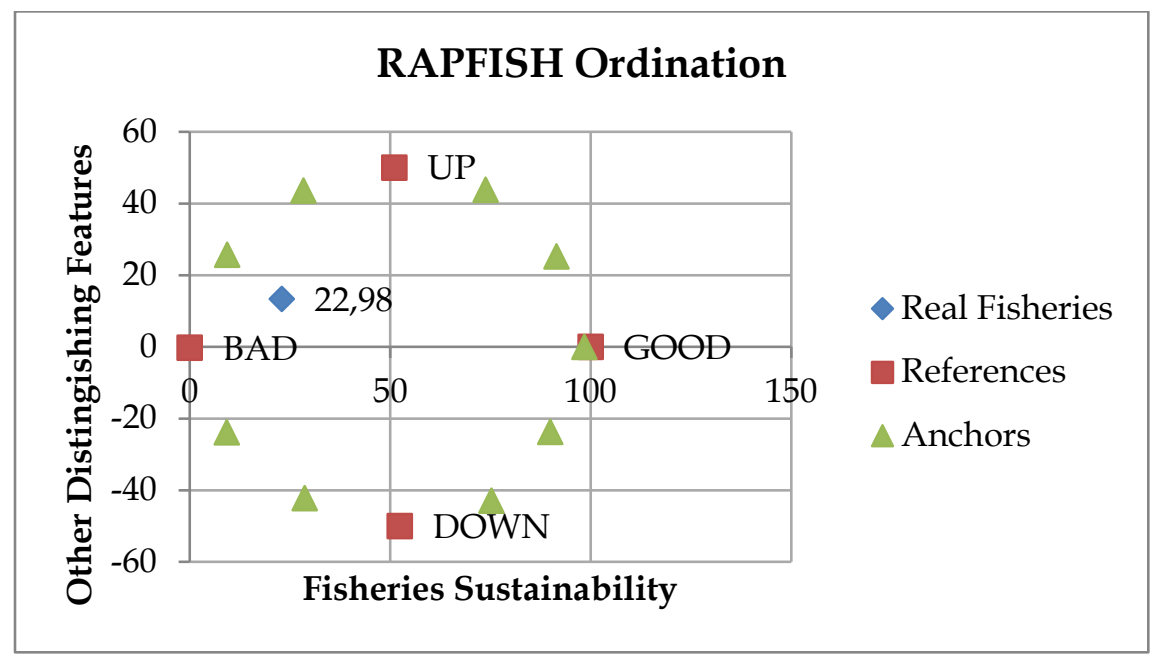

Gambar 2

Rap Analisis Dimensi Ekologi Budidaya Bandeng

Hasil analisis sensitivitas dimensi ekologi menunjukkan atribut paling sensitif yaitu ketersediaan air dengan nilai sebesar 11,80 (Gambar 3). Perubahan sedikit pada atribut ini akan mempengaruhi status keberlanjutan usaha budidaya bandeng pada dimensi ekologi (Faridz et al. 2018). Atribut ketersediaan air membutuhkan pengelolaan dengan baik agar aspek dimensi ekologi dapat ditingkatkan.

Air merupakan sumberdaya utama dalam mengusahakan komoditas perikanan bandeng. Dibangunnya pabrik dan kawasan perumahan di sekitar wilayah kurang berdampak terhadap ketersediaan jumlah air yang dibutuhkan dalam usaha budidaya. Namun, hal tersebut tetap harus mendapat perhatian khusus untuk mendukung keberlanjutan. Secara teknis terpenuhinya jumlah air yang dibutuhkan petani akan mempermudah dalam mendukung usaha budidaya bandeng. Permasalahan ketersediaan air dipengaruhi langsung oleh saluran air di wilayah tambak Desa Banyuwangi Kecamatan Manyar Gresik yang tidak memadai. Saluran air hanya berupa galian memanjang yang hanya akan terisi apabila air laut pasang. Jumlah air yang ditampung dalam saluran air tersebut juga terbatas, sehingga perlu adanya perbaikan lebih lanjut untuk mendukung ketersediaan air.

Pembangunan pabrik di sekitar wilayah menyebabkan pencemaran perairan $(1,95)$ akibat pembuangan limbah pabrik sekitar wilayah yang langsung menuju laut. Pencemaran perairan yang tinggi memberikan dampak tersendiri terhadap usaha budidaya bandeng seperti perubahan warna pada sumberdaya air yang digunakan oleh petani. Kurangnya 
pengawasan penggunaan bahan kimia juga dapat menjadi faktor terjadinya pencemaran lingkungan (Mufa'ah \& Hayati, 2016). Namun, usaha budidaya masih dapat dilakukan dengan menggunakan air tersebut. Bandeng merupakan jenis ikan yang memiliki daya toleransi yang tinggi terhadap lingkungan, perubahan kadar garam dan suhu tinggi (Mas'ud, 2011) sehingga petani masih dapat bertahan di tengah kondisi perairan yang kurang baik.
Hasil di atas berbeda dengan hasil penelitian Muliawan et al. (2016) di Kabupaten Gresik. Hasil ordinasi rapfish menunjukkan dimensi ekologi memiliki status cukup berkelanjutan dengan nilai indeks 33,77. Atribut dimensi ekologi yang paling sensitif adalah tekanan terhadap lingkungan darat (mangrove). Lahan tambak yang dikembangkan di daerah penelitian mengkonversi hutan mangrove sehingga kawasan tersebut rawan terjadi alih fungsi pemanfaatan.

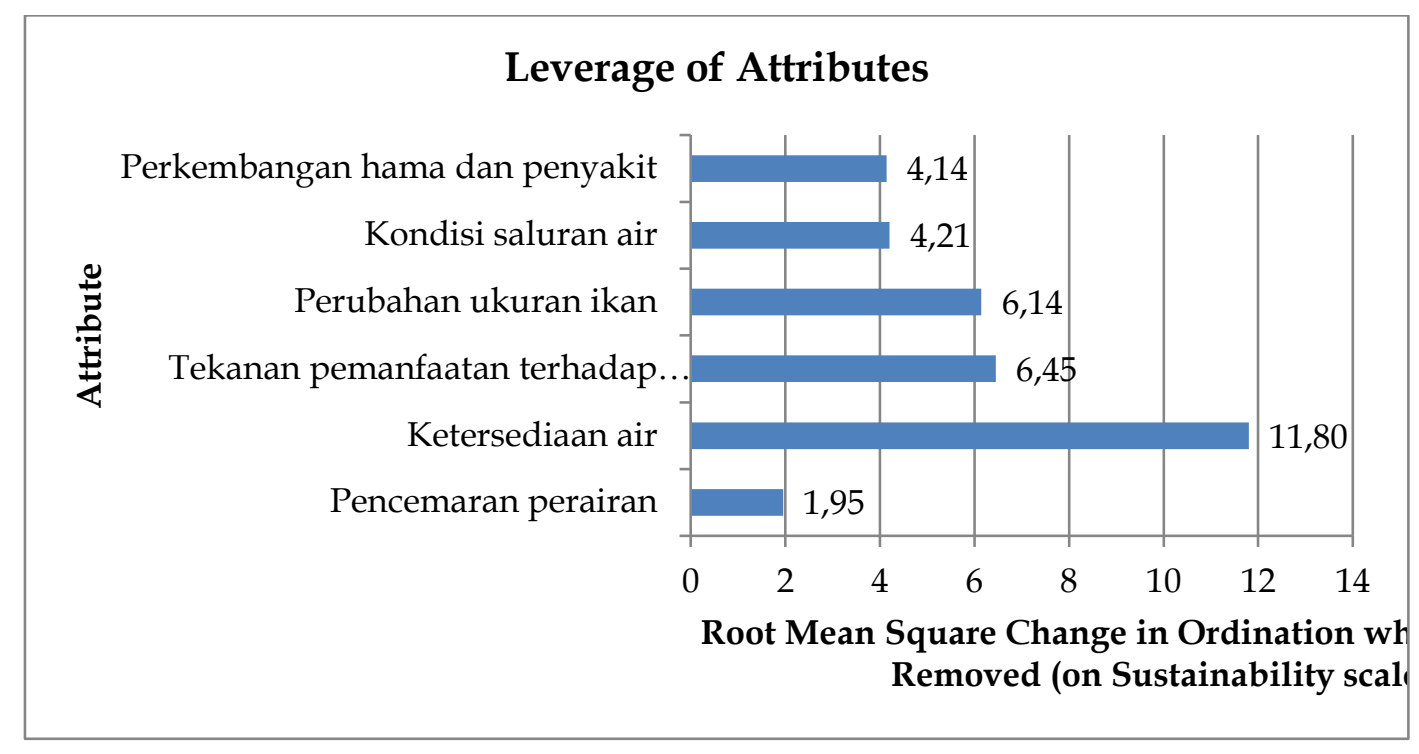

\section{Gambar 3}

Analisis Laverage Dimensi Ekologi Budidaya Bandeng

\section{Status Keberlanjutan Dimensi Ekonomi}

Hasil analisis status keberlanjutan dimensi ekonomi menunjukkan nilai indeks sebesar 40,90 (Gambar 4). Nilai tersebut menunjukkan status keberlanjutan usaha perikanan budidaya bandeng kurang berkelanjutan dengan nilai indeks pada skala 25,01-50,00. 


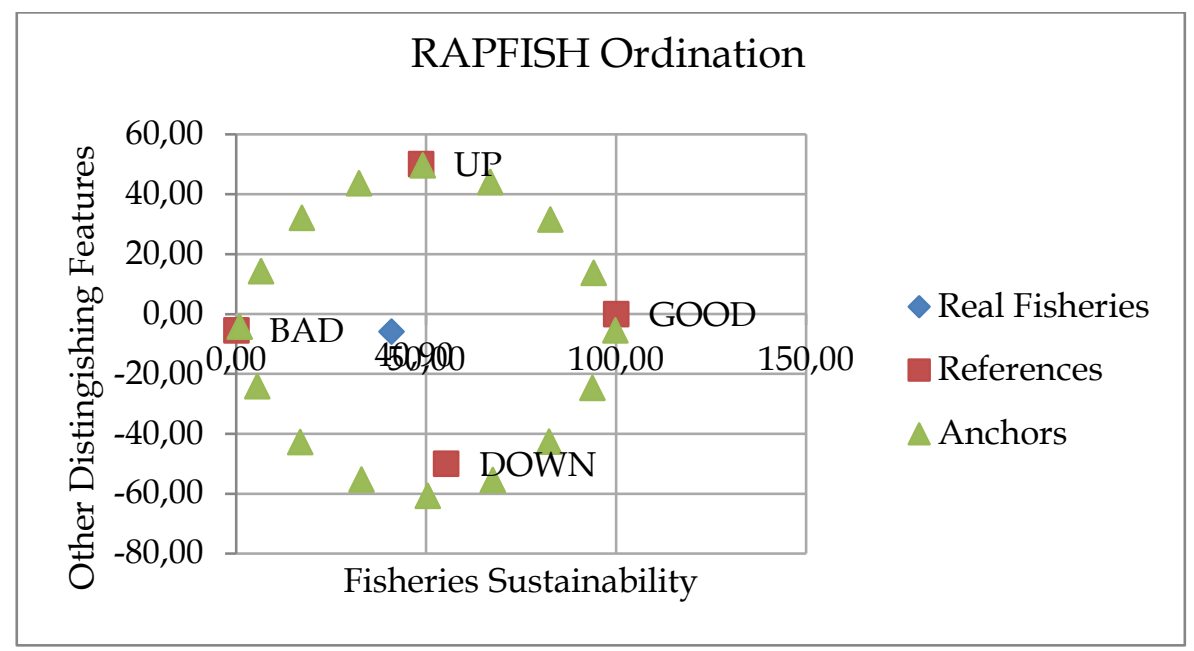

\section{Rap Analisis Dimensi Ekonomi Budidaya Bandeng}

Berdasarkan analisis laverage dimensi ekonomi pada Gambar 5 menunjukkan atribut paling sensitif terhadap keberlanjutan budidaya bandeng yaitu subsidi (7,39), permintaan ikan $(7,34)$, persaingan antar petambak $(7,14)$, harga ikan $(6,45)$, dan pendapatan $(5,46)$. Atribut yang sensitif adalah atribut yang dapat berperan sebagai penghambat atau pendukung keberlanjutan dalam usaha budidaya bandeng di Kecamatan Manyar Kabupaten Gresik. Semakin besar peranan atribut dalam meningkatkan keberlanjutan maka akan semakin besar pula nilai RMS yang muncul (Nirgasari, 2015).

Atribut yang paling sensitif yaitu atribut subsidi sebesar (7,39). Atribut ini dapat menjadi faktor pendorong keberlanjutan usaha budidaya bandeng di Kecamatan Manyar. Hal tersebut dikarenakan petani tambak di Desa
Banyuwangi tidak pernah merasakan adanya bantuan baik berupa materi maupun subsidi operasional dari pemerintah. Dana pengelolaan tambak sepenuhnya ditanggung oleh petani. Pengusahaan bantuan dana hanya dilakukan oleh kelompok untuk meringankan biaya operasional yang dikeluarkan oleh petani dalam mengusahakan komoditas bandeng.

Atribut sensitif selanjutnya adalah permintaan ikan dengan nilai sebesar $(7,34)$. Atribut permintaan ikan merupakan atribut dengan nilai paling tinggi kedua yang berarti salah satu faktor penting pendorong keberlanjutan usaha budidaya bandeng di Kecamatan Manyar. Permintaan ikan yang cenderung mengalami kenaikan setiap tahunnya menjadi faktor pendorong petani untuk tetap mengusahakan bandeng. Menurut 
Najah et al. (2019) kebutuhan permintaan bandeng naik secara signifikan akibat meningkatnya minat konsumsi lokal terhadap komoditas bandeng. Selain itu, peningkatan permintaan bandeng juga diakibatkan oleh kebutuhan ekspor dan kegiatan industri (Laksono, 2020).

Atribut yang sensitif selanjutnya yaitu persaingan antar petambak yang berada pada urutan ketiga dengan nilai sebesar (7,14). Persaingan merupakan kompetisi untuk mendapatkan keuntungan sebesar-besarnya, namun di kawasan tambak Desa Banyuwangi Kecamatan Manyar tidak terdapat persaingan dalam melakukan budidaya bandeng. Petani telah memiliki cara dan saluran pemasaran (langganan) masing-masing dalam menjual hasil budidaya. Petani biasanya menjual bandeng langsung kepada tengkulak yang datang untuk membeli hasil produksinya

Atribut keempat yang paling sensitif yaitu Harga ikan $(6,45)$. Harga ikan bandeng cenderung relatif stabil dibandingkan harga ikan lainya. Harga yang ditawarkan petani di kawasan tambak Kecamatan Manyar berkisar antara 11.00017.000 per $\mathrm{kg}$ tergantung ukuran ikan. Atribut terakhir yang menjadi atribut paling sensitif yaitu Pendapatan. Sebagian besar masyarakat di kawasan tambak banyuwangi menjadikan tambak sebagai sumber mata pencaharian utama yakni sebesar $71 \%$ dari total responden. Kondisi ini menjadi faktor pendorong keberlanjutan usaha budidaya bandeng di Kecamatan Manyar. Budidaya bandeng menjadi salah satu penopang utama perekonomian di daerah tersebut. Kondisi kehidupan yang berkecimpung pada usaha budidaya bandeng membuat petani banyak menggantungkan aspek ekonominya pada tambak bandeng.

Nilai terendah dalam analisis sensitivitas adalah biaya usahatani $(0,13)$. Biaya adalah sejumlah pengorbanan yang dikeluarkan untuk melakukan proses produksi. Dalam kegiatan usahatani bandeng di Kecamatan Manyar, petani harus mengeluarkan biaya berupa bibit, pakan, obat, pupuk dan biaya operasional (solar). Setiap tahun biaya yang dikeluarkan petani selalu mengalami peningkatan. Setahun terakhir biaya yang dikeluarkan oleh petani bandeng di wilayah Desa Banyuwangi Kecamatan Manyar mengalami peningkatan sebesar $30 \%$. Biaya usahatani akan terus meningkat setiap tahunnya sehingga petani mengharapkan adanya bantuan dana (subsidi) dari pemerintah terhadap usaha budidaya bandeng yang dilakukan.

Hasil penelitian diatas menunjukan hasil yang selaras dengan penelitian 
Muliawan et al. (2016) di Kabupaten Gresik. Pada dimensi ekonomi hasil ordinasi rapfish berada pada nilai indeks sebesar 43,11 yang artinya cukup berkelanjutan. Atribut yang paling sensitif adalah lokasi tujuan dan orientasi pemasaran perikanan. Tujuan pasar harus diubah untuk memperoleh penerimaan yang lebih besar yakni kepada konsumen akhir. Hal tersebut bertujuan untuk meningkatkan kesejahteraan petani dalam usaha budidaya bandeng.

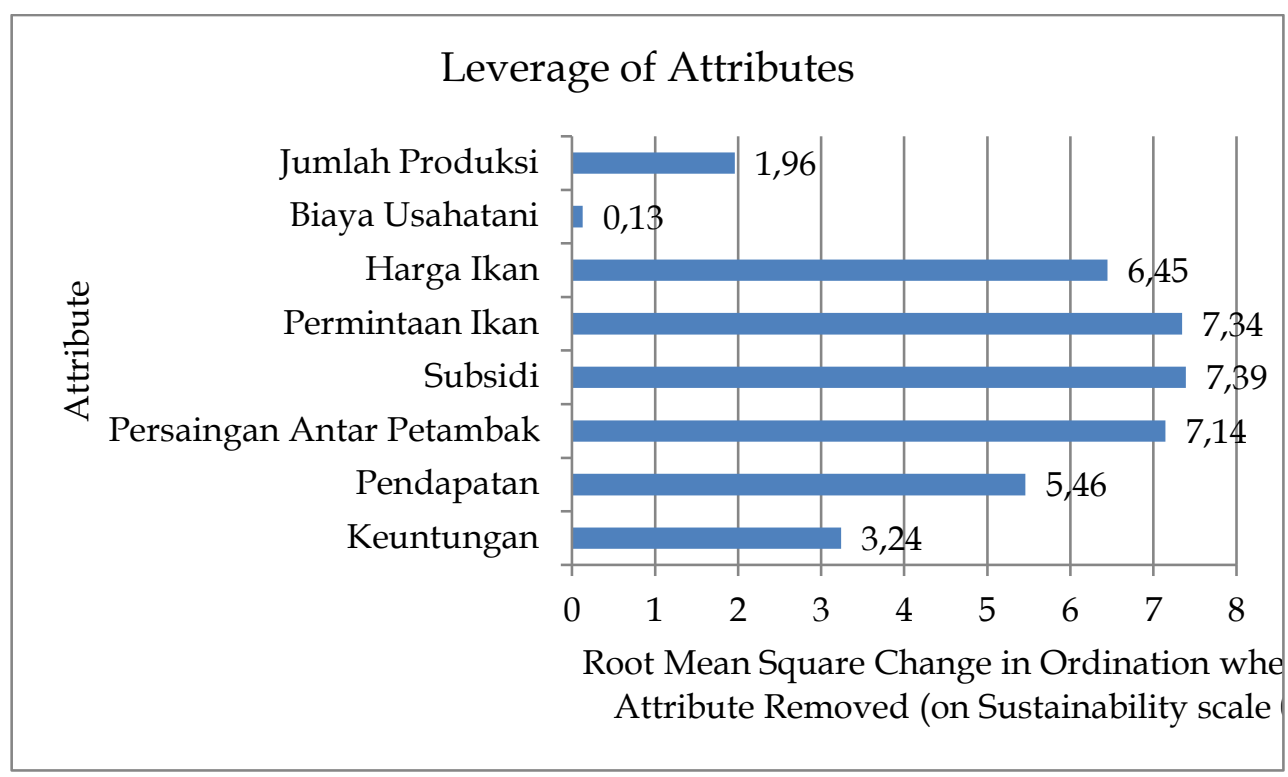

Gambar 5

Analisis Laverage Dimensi Ekonomi Budidaya Bandeng

\section{Status Keberlanjutan Dimensi Sosial}

Hasil analisis rapfish yang telah dilakukan menunjukkan nilai indeks sebesar 43,45 (Gambar 6) yang artinya usaha budidaya bandeng di Kecamatan Manyar kurang berkelanjutan karena nilai indeks berada pada skala 25,01-50,00. 


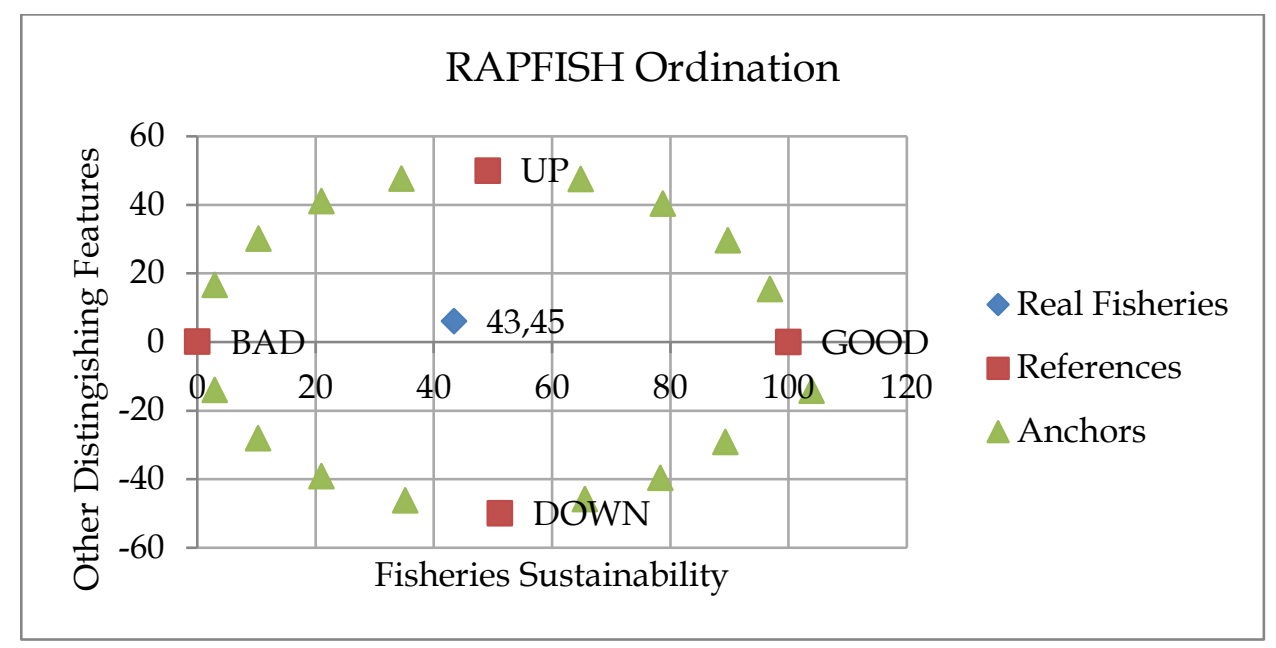

Sumber: Data Primer Diolah, (2021)

\section{Gambar 6}

\section{Rap Analisis Dimensi Sosial Budidaya Bandeng}

Hasil analisis leverage dimensi social pada Gambar 7 menunjukkan bahwa atribut yang paling berpengaruh terhadap usaha budidaya bandeng di Kecamatan Manyar yaitu ketergantungan petani terhadap sektor perikanan bandeng $(7,73)$ dan frekuensi pertemuan antar petambak untuk pengelolaan sumberdaya $(5,82)$. Kedua atribut tersebut memerlukan perhatian agar keberlanjutan perikanan budidaya bandeng dimensi sosial dapat ditingkatkan.

Atribut pertama yang memiliki nilai RMS terbesar adalah ketergantungan petani terhadap sektor perikanan $(7,73)$. Sebagian besar masyarakat di kawasan tambak Kecamatan Manyar menggantungkan pendapatan keluarga pada budidaya bandeng. Sebanyak 70\% responden menjadikan budidaya bandeng sebagai sumber mata pencaharian utama, sedangkan sisanya sebanyak $30 \%$ memiliki pekerjaan lain seperti karyawan pabrik, buruh tani, buruh pabrik, kuli bangunan, usaha warung, pedagang dan buruh proyek yang pendapatannya kurang dapat mencukupi kebutuhan keluarga.

Atribut sensitif kedua yaitu frekuensi pertemuan antar pertambak untuk membicarakan pengelolaan sumberdaya (5,82). Petani di kawasan tambak Desa Banyuwangi sangat jarang melakukan pertemuan antar petani untuk membicarakan permasalahan maupun pengelolaan budidaya. Namun, petani telah mulai berkembang dalam persoalan tersebut, terbukti dari terbentuknya kelompok tani bernama "Keluarga Wangi Sejahtera Abadi" yang terbentuk pada tanggal 30 Maret 2021. Berdasarkan 
kondisi demikian membuat atribut ini menjadi atribut sensitif yang menunjang keberlanjutan usaha budidaya bandeng di Kecamatan Manyar.

Nilai terendah pada analisis sensitivitas adalah keinginan meninggalkan lokasi $(0,47)$. Seluruh responden penelitian berkeinginan untuk meninggalkan tambak budidaya di Kecamatan Manyar namun belum terencana waktunya. Hal tersebut dipengaruhi oleh ketergantungan petani terhadap usaha budidaya bandeng. Sebanyak $71 \%$ responden penelitian menggantungkan pendapatan keluarga dari usaha budidaya dan tidak memiliki sumber pendapatan lain. Selain itu, $50 \%$ responden berusia $\geq 50$ tahun sehingga akan sulit mencari pekerjaan baru untuk mendapatkan sumber pendapatan.

Hasil penelitian tersebut berbeda dengan hasil penelitian Muliawan et al. (2016) di Kabupaten Gresik dan Nirgasari (2015) di Kabupaten Sidoarjo yang menunjukkan hasil hasil cukup berkelanjutan, nilai indeks masing-masing 52,92 dan 65,56 pada dimensi sosial. Pada penelitian Muliawan (2016) atribut yang paling sensitif yaitu tingkat pendidikan dan partisipasi keluarga. Alasan atribut tersebut menjadi yang paling sensitif yaitu tingkat pendidikan dapat menjadi indikator pola pemanfaatan teknologi dan penanganan limbah pada lahan mangrove. Sedangkan partisipasi keluarga dapat memudahkan pembentukan masyarakat kelompok untuk pengelolaan suberdaya perikanan berkelanjutan. Pada penelitian Nirgasari (2015) atribut paling sensitif yaitu konflik dalam masyarakat, partisipasi petambak dalam pengambilan keputusan dan pemahaman lingkungan oleh petambak. Atribut konflik dalam masyarakat dan pemahaman lingkungan merupakan atribut pendorong keberlanjutan sedangkan atribut partisipasi petambak merupakan atribut sensitif yang menghambat keberlanjutan. 


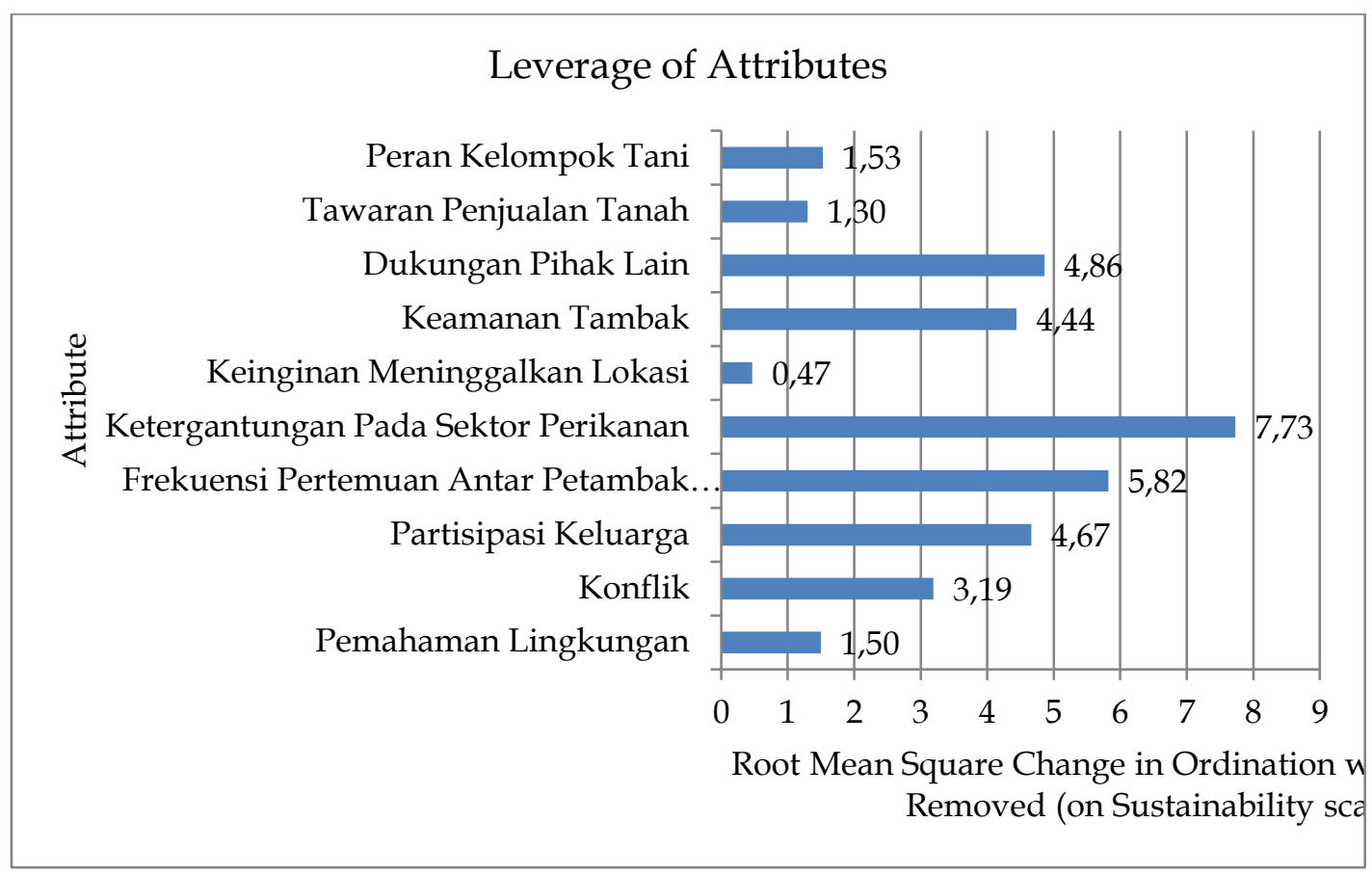

Sumber: Data Primer Diolah, (2021)

Gambar 7

Analisis Laverage Dimensi Sosial Budidaya Bandeng Kecamatan Manyar

\section{KESIMPULAN DAN SARAN}

Berdasarkan hasil penelitian dapat disimpulkan bahwa usaha budidaya bandeng di Kecamatan Manyar Kabupaten Gresik kurang berkelanjutan. Adapun status keberlanjutan masing-masing dimensi adalah dimensi ekologi berkategori buruk, dimensi ekonomi dan dimensi sosial kurang berkelanjutan $(43,45)$. Saran pada penelitian ini yaitu adanya perhatian lebih dari pemerintah terhadap kawasan budidaya di Kecamatan Manyar diantaranya pembangunan saluran air yang memadai, penguatan kelompok tani dan adanya subsidi terhadap biaya operasional seperti pupuk, pakan dan obatobatan.

\section{DAFTAR PUSTAKA}

Abdullah, R. M., Wisudo, S. H., Monintja, D. R., \& Sondita, M. F. A. (2011). Keberlanjutan Perikanan Tangkap di Kota Ternate pada Dimensi Ekologi. Buletin PSP, 19(1), 113126.

Ali, S. A. (2019). Rapfish Analysis to Assess the Status of the Sustainability of Capture Fisheries Systems in Bone Bay. International Journal of Science and Research, 6(9), 817-826. https://doi.org/10.21275/ART2017 6104

Ambarini, N. S. B., Satmaidi, E., \& Sofyan, T. (2018). Pengembangan Usaha Perikanan Berbasis Kearifan Lokal dalam Pengelolaan Sumber Daya Kelautan Berkelanjutan di Bengkulu. Bina Hukum Lingkungan, 2(2), 182-197. 
Amna. (2014). Analisis Pengelolaan Teknik Rapfish Terhadap Ketersediaan Cakalang (Katsuwonus pelamis) di Perairan Pesisir Aceh Barat. Skripsi, 1-59.

Anggraini, A. C. W., \& Sulistyarso, H. (2014). Arahan Optimasi Produksi Perikanan Budidaya Bandeng Melalui Konsep Community Based Natural Resource Management (CBNRM) pada Kecamatan Manyar Kabupaten Gresik. Jurnal Teknik ITS, 4(1), 1-5.

Arsyad, I., Darman, S., \& Rizal, A. (2016). Analisis Keberlanjutan Kawasan Minapolitan Budidaya di Desa Sarasa Kecamatan Dapurang Kabupaten Mamuju Utara. Jurnal Sains Dan Teknologi Tadulako, 5(1), 72-77.

Asche, F., Garlock, T. M., Anderson, J. L., Bush, S. R., Smith, M. D., Anderson, C. M., ... Vanuccini, S. (2018). Three Pillars Of Sustainability In Fisheries. PNAS, 115(44), 11221-11225.

Atmaja, S. B., \& Nugroho, D. (2011). Upaya-Upaya Pengelolaan Sumberdaya Ikan yang Berkelanjutan di Indonesia. Jurnal Kebijakan Perikanan, 3(2), 101113.

Badan Pusat Statistik. (2019). Gresik Dalam Angka 2019. (B. P. S. Gresik, Ed.). Gresik: CV. Dwi Anugrah Jaya.

Barclay, K. (2012). The Social in Assessing for Sustainability Fisheries in Australia. Cosmopolitan Civil Societies, 4(3), $38-53$.

Erwina, Y., Kurnia, R., \& Yonvitner. (2015). Status Keberlanjutan
Sumberdaya Perikanan di Perairan Bengkulu. J. Sosek Kp, 10(1), 2134.

Faridz, R., Ariffin, Soemarno, \& Pramoedyo, H. (2018). Indeks dan Status Keberlanjutan Ketersediaan Tembakau Madura. Jurnal Sosial Ekonomi Dan Kebijakan Pertanian, 7(2), 188-208.

Graha, P. S. N. W. (2017). Analisis Status Keberlanjutan Pengelolaan Pembenihan Ikan Bandeng Skala Rumah Tangga (HSRT) di Desa Penyabangan Kecamatan Gerokgak Kabupaten Buleleng Provinsi Bali. Skripsi, 1-80.

Kementrian Kelautan dan Perikanan. (2018). Refleksi Outlook. Kementrian Kelautan dan Perikanan.

Laksono, S. A. (2020). Analisa Kelayakan Usaha Budidaya Bandeng (Chanoschanos) di Desa Pangkah Wetan Kecamatan Ujung Pangkah, Kabupaten Gresik. Skripsi, 1-12.

Mas'ud, F. (2011). Prevalensi dan Derajat Infeksi Dactylogyrus sp. pada Insang Benih Bandeng (Chanos chanos) di Tambak Tradisional, Kecamatan Glagah, Kabupaten Lamonga. Jurnal Ilmuah Perikanan Dan Kelautan, 3(1), 27-40.

Mufa'ah, \& Hayati, M. (2016). Analisis Daya Saing Ekspor Komoditas Udang Indonesia. AGRIFO, 1(1), $1-20$.

Muliawan, I., Zamroni, A., \& Priyatna, F. (2016). Kajian Keberlanjutan Pengelolaan Budidaya Ikan Bandeng di Gresik. Jurnal Kebijakan Sosek, 6(1), 25-35.

Nababan, B. O., Sari, Y. D., \& Hermawan, 
M. (2007). Analisis Keberlanjutan Perikanan Tangkap Skala Kecil di Kabupaten Tegal Jawa Tengah (Teknik Pendekatan Rapfish). Bijak Dan Riset Sosek, 2(2), 137-158.

Najah, D. A., Rinianti, \& Priyanto, F. W. (2019). Elastisitas, Skala Ekonomi dan Efisiensi Produksi Budidaya Ikan Bandeng pada Sentra Perikanan di Tanjung Widoro Desa Mengare Kabupaten Gresik. Jurnal Ekonomi Dan Bisnis GROWTH, 17(1), 88-96.

Nirgasari. (2015). Tingkat Motivasi dan Analisis Keberlanjutan Petambak Udang Vanname (Litopanaeus Vannamei) Pasca Semburan Lumpur Panas Di Kecamatan Tanggulangin Kabupaten Sidoarjo. Skripsi, 1-125.

Nurmalina, R. (2008). Analisis Indeks dan Status Keberlanjutan Sistem Ketersediaan Beras di Beberapa Wilayah Indonesia. Jurnal Agro Ekonomi, 26(1), 47-79.

Purwaningsih, R., \& Santosa, H. (2015). Pengembangan Metode Penilaian Keberlanjutan (Sustainability Assessment) Klaster Industri Perikanan. In SNST (pp. 1-6).

Rane, M. K. D., Ridwan, M. S., \& Wardah. (2019). Pengaruh Kualitas
Layanan, Biaya Pendididikan dan Fasilitas Pendidikan terhadap Keputusan Konsumen dengan Brand Image sebagai Variabel Intervening dalam Memilih Program Studi Pada Fakultas Ekonomi Universitas Kristen Artha Wacana Kupang. Jurnal Ekonomi Dan Bisnis, 4(1), 869-880.

Rice, J. (2014). Evolution Of International Commitments For Fisheries Fustainability. Marine Science, 71(2), 157-165.

Setianingtias, R., Baiquni, M., \& Kurniawan, A. (2019). Permodelan Indikator Tujuan Pembangunan Berkelanjutan di Indonesia. Jurnal Ekonomi Dan Pembangunan, 27(2), 61-74.

Wijaya, B. P. Y., \& Rachmawati, R. (2017). Pengembangan Kegiatan Perikanan dan Peran Kelembagaan Masyarakat di Kawasan Minapolitan Kabupaten Gresik. Jurnal Bumi Indonesia, 6(3), 1-10.

Zakiyah, D. M. (2014). Pengembangan Perikanan Budidaya: Efektivitas Program Minapolitan dalam Pengelolaan Perikanan Budidaya Berkelanjutan di Kabupaten Gresik. Jurnal Pembangunan Wilayah \& Kota, 10(4), 453-465. 